\title{
Old Genres in New Attire: Zsolna Ugron's Novels
}

\author{
Boróka PROHÁSZKA-RÁD \\ Sapientia Hungarian University of Transylvania (Miercurea Ciuc, Romania) \\ Department of Humanities \\ prohaszkaboroka@uni.sapientia.ro \\ Boróka SALAMON \\ Sapientia Hungarian University of Transylvania (Miercurea Ciuc, Romania) \\ Translation-Interpretation MA Programme \\ salamonboroka@yahoo.com
}

\begin{abstract}
In the present study we propose a look at Zsolna Ugron's works from a generic perspective in order to analyze what conventions of genres such as the romance, the epistolary novel and the historical romance the author has revived and what are the elements that she has added or changed in order to make them appealing to the public and yield to critical analysis. We also attempt an investigation of the formation of female subjectivity as illustrated by these fundamentally feminine novels, given that all four of them operate with female protagonists, women in the process of shaping their destinies, often at crossroads where - despite all the external factors that seem to determine their fate from history to social conventions and men around them - ultimately they make their own personal choices and position themselves as responsible, active and creative subjects.
\end{abstract}

Keywords: Zsolna Ugron, genre, subject, canon, popular literature.

\section{Introduction}

Zsolna Ugron's novels have generated a lasting buzz among the reading public both in Hungary and Transylvania. ${ }^{1}$ Literary criticism, however, seems to ignore

1 Zsolna Ugron (Cluj-Napoca, 1978-), like her heroines, seems to be constantly reinventing herself. Born in Transylvania from an old aristocratic family, she then moved with her family to Hungary. After her studies in law school she worked as a journalist, TV editor and reporter, communication advisor, but she has also edited and hosted cooking shows and documentaries, and she has actively participated in the renovation and interior design of Transylvanian castles regained by their owners after the fall of communism and long restitution suits. In 2013 she also published a recipe book spiced with short stories, Hét évszak. Receptek és történetek [Seven Seasons. Recipes and Stories], a volume already expected by her readers given that her first 
her work - as the author herself stated in an interview: "I think contemporary literature does not really notice me" (Benedek 2014). ${ }^{2}$ This may be due to the fact that all four of her novels discussed here fall into the category of what is called popular fiction - something that literary criticism and theory does not concern itself much with. Especially given the generic attributes of the novels: her first, Úrilányok Erdélyben [By the Black River - A Transylvanian (Love) Story] published in 2010 was publicized as a "postmodern girls' novel," the second, Szerelemféltók [The A - B Dialogue], written together with Zsolt Meskó (2011) regenerates the epistolary tradition of Hungarian literature, while Erdélyi Menyegzó [Splendour] (2013) and A nádor asszonyai [The Palatine's Women] (2014) are part of a planned historical trilogy, subgenres not much discussed by criticism and neither very fashionable from the perspective of the literary canon of today. ${ }^{3}$ Still, the public seems to receive them with enthusiasm: her first novel went out of print and now its second edition is available to the public, while the other three works also topped the charts for weeks.

In the present study we propose a look at these works from a generic perspective in order to analyze what elements of the above mentioned old genres the author has revived and what are the elements that she has added or changed in order to make them appealing to the public and yield to critical analysis. ${ }^{4}$ We also attempt an investigation of the formation of female subjectivity as illustrated by these fundamentally feminine novels, given that all four of them operate with female protagonists, women in the process of shaping their destinies, often at crossroads where - despite all the external factors that seem to determine their fate from history to social conventions and men around them - ultimately they make their own personal choices and position themselves as responsible, active and creative subjects.

novel also originated from the idea of publishing a hand-written recipe book inherited from her grandmother which also contained a collection of her great-grandmother's recipes (Varga 2011); and in 2016 a fifth novel under the title Hollóasszony [Ravenwoman]. Similarly to her novels, she defies categorization, subverting even the idea of clear-cut limits of any subject position or genre.

2 A study addressing, among other contemporary literary and cinematographic works, also Ugron's first novel was published by Andrea Virginás in 2014.

3 The literal translation of Úrilányok Erdélyben would be Young Ladies in Transylvania. The English title used in the present study was suggested by the author's publisher, which they use as a working title while preparing the novel for its English publication. The historical trilogy bears the Hungarian title Úrasszonyok (the literal translation of which is Ladies), while the first volume's title Erdélyi Menyegzó means Transylvanian Wedding. At present the publisher is using as working title of the translation of both the trilogy and of the first volume Splendour.

The success of Ugron's novels may also be attributed to the fact that since the 1990s the Hungarian reading public has been accustomed to a revival of old genres such as the historical novel, romance and even the epistolary genre through the works of authors such as Péter Esterházy, György Spiró, Zsuzsa Rakovszky, Andrea Tompa and others, while "chick lit" or "girls' prose" works have also been present in bookshops and enjoyed much of the public's attention - novels by Éva Fejős, Virág Vass, Fábián Janka, and more recently Hargita Szász. 


\section{Blurred Genres, Popular Literature and the Canon}

Úrilányok Erdélyben [By the Black River] opens with a short text entitled "In lieu of a preface” (2010, 5-7). As János Orbán states,

[t]raditionally the preface [...] summarizes, presents and locates the text possibly the author - in a context. Thus, with the security of a 'hidden' and 'omnipotent' author it draws textual limits around the text within the text, and tries to link to the external reality a text not yet read by the reader but already contoured by the preface. Thus it sets up a preliminary horizon of expectations. (qtd. in Palkó 2003, 502)

Despite the title suggesting a text avoiding the functions ascribed to prefaces, Ugron uses this short introduction to position herself as the author of the following novel as the descendant of an old aristocratic family from Transylvania, living and working in Budapest, whose busy city life changes drastically when she marries and moves to a small Transylvanian village. She also locates her text, stating: "life has inscribed me into a (girls') novel very similar to this one" $(2010,7)$, establishing thus the genre and accordingly setting up readers' expectations from the very outset. However, already this short preface masquerading as the author's autobiographical note foreshadows the subversion of the very genre it argues the text would be. Beyond the autobiographical elements (the identification and validation of which does not constitute the aim of the present study), the novel will lead its reader into history:

When we moved back [to Transylvania], together with the uncertainties of the future the past also overwhelmed me and I started to search for some support. Piecing together stories from my childhood, anecdotes, reading memoires and badgering people with questions and through research, I began to see the shape of a lifestyle mementos of which were the ruinous castles and manors [...]

I do not think that we should live in the past, neither that we should revive that world and bring it into our own lives. Not even if history's whim has allowed some of us to return to the castles. But I do believe that we have to preserve the pieces that we still can and we have to know their place. I think one cannot escape history - you have to deal with it. (Ugron 2010, 6-7)

The field of readers' expectations widens to incorporate elements of the historical novel, while the stated genre (girls' novel) evokes conventions of the

5 Quotations from texts not available in English are all translations of the authors of the present study. 
sentimental novel. The main text, divided into chapters, is farther segmented by the embedded anecdotes of the above mentioned past lifestyle (printed in italics), and ends with a collection of ten recipes from the family recipe book, including the "fabulous" rabbit-pate for snack (Ugron 2010, 287) and the "Tomato-assiette as starter for summer dances" (Ugron 2010, 299).

Such blurring of genres (to use Geertz's term) and subversion of generic limits and conventions are often regarded by literary criticism and theory characteristic traits of postmodern works. At the same time, discussions about the postmodern also frequently focus on the relations between popular literature, within it the so-called feminine genres, and high literature and the canon. It has been argued that types of novels that traditionally have been viewed as popular fiction and have been therefore neglected by critics and theoreticians (such as detective stories, historical romances, crime fiction, science fiction, fantasy and many other subgenres of fiction) have been, on the one hand, "invisible for professional readers" (Bárány 2011), while on the other, due to this subversion and blurring of genres they enter the mainstream in order to be ironically rewritten and deconstructed. ${ }^{6}$ At the same time, literary criticism has shown that often works appealing to a large reading public - for various reasons among which generic, thematic, or the fact that such works generally require conservative interpretation attitudes - may yield to professional analysis and from such a perspective they may offer fertile ground for new interpretations and open up paths of discussions on issues of genre, cultural policy, etc. ${ }^{7}$ Despite, then, that popular fiction has been lingering at the rim of the literary canon, mostly outside of theoreticians' and critics' horizons, as Zsuzsa Tapodi states, the present cultural world seems to suggest that we are witnessing if not the disappearance of canons, then surely their reorganization, similar to the phenomena initiated by Romanticism or the Avant Garde which led to a radical reshaping of literary maps (2008, 35). Geertz's argument states the same:

[...] the present jumbling of varieties of discourse has grown to the point where it is becoming difficult either to label authors [...] or to classify works [...] It is a phenomenon general enough and distinctive enough to suggest that what we are seeing is not just another redrawing of the cultural map the moving of a few disputed borders [...] - but an alteration of the principles of mapping. Something is happening to the way we think about the way we think. $(1980,165)$

6 As Bárány states, despite the negative value judgment with reference to popular genres, Hungarian literary criticism's interest in these types of works has livened in recent years (Bárány mentions the studies of Tamás Bényei, Éva Bánki, Anna Menyhért and others).

7 See, for example, Klaudia Papp's (2007) study on Anita Brookner's Hotel du Lac; Gabriella Moise's (2007) reading of Sarah Dunant's The Birth of Venus. 
With reference to the relation between the literary canon and popular literature Tapodi discusses the issue in terms of the centre and periphery, referring to Itamar Even Zohar's argument according to whom the dynamics of literary systems displays itself as a continuous centre-periphery movement, where one of the main levers consists in the tension between canonical and non-canonized literature. Therefore, without a strong subculture canonized culture stiffens and will not be able to keep up with society's demand for change. Accordingly, "[d]evelopment moves elements of the periphery to the centre, thus a genre that earlier was regarded as barely presentable becomes fashionable and a model to follow, while another that used to be in the centre of the canon becomes obsolete and is delegated to the periphery" (Tapodi 2008, 35). Such permanent shifting within "a situation at once fluid, plural, uncentered and ineradicably untidy" (Geertz 1980, 165) calls for attention to genres at present on the periphery and authors such as Ugron, whose first success novel did not remain a "one-hit-wonder" but was followed by the large public's enthusiastic interest in her farther works. Even more so if we consider Péter Szirák's claim in his discussion of Hungarian literary postmodernism that "in the shaping of cultural relations in Hungary postmodern components are noticeably involved" such as "the blurring of borders between elite- and consumer-cultures" (2001, 37). A similar argument comes from John Storey:

Perhaps the most significant thing about postmodernism for the student of popular culture is the recognition that there is no absolute categorical difference between high and popular culture. This is not to say that one text or practice might not be "better" (for what/for whom, etc., must always be decided and made clear) than another text or practice. But it is to say that there are no longer any easy reference points that will automatically preselect for us the good from the bad. Some might regard such a situation [...] with horror - the end of standards. On the contrary, without easy recourse to fixed categories of value, it calls for rigorous, if always contingent, standards, if our task is to separate the good from the bad. [...]

Postmodernism has certainly changed the theoretical and the cultural basis on which to think about popular culture. In fact, the collapse of the distinction (if this is the case) between high and popular culture may signify that at last it may be possible to use the term popular culture and mean nothing more than culture liked by many people. (2003, 156-157)

Regarding value he also states: "the cultural text under the sign of the postmodern is not the source of value, but a site where the construction of value - variable values - can take place” $(2003,156)$, referring to Fredric Jameson's concepts of postmodern culture as one of pastiche, "a world in which stylistic innovation is no longer possible, all that is left is to imitate dead styles, to speak through the 
masks and with the voices of the styles in the imaginary museum" (qtd. in Storey 2003, 150). Discussing postmodernism and literature Barry Lewis also relies on Jameson when stating that "[p]astiche is [...] a kind of permutation, a shuffling of generic and grammatical tics" $(2003,125)$, arguing that many contemporary novels "borrow the clothes of different forms," listing among the characteristics of postmodern texts - beyond the above quoted "cross-dressing" $(2003,126)$ also fragmentation, where generic conventions may be followed without leading to a regular representative text of the given genre (Lewis exemplifies this with John Fowles's The French Lieutenant's Woman, which "follows several love story conventions [but] it is far from being a regular historical romance" $(2003,127))$, fragmentation also manifesting itself in "breaking up the text into short fragments or sections," the disjointed character of the "very fabric of the text" with the inclusion of illustrations, typography (like the use of multiple typefaces), or mixed media $(2003,127)$.

Cross-dressing, fragmentation, the merger of discourses, of spatial and temporal planes, the destabilization of chronology with the technique of framing as well as embedded narratives also characterize Ugron's novels, among them By the Black River, which bears the subtitle "Postmodern girls' novel about dreams, love, castles..." on a title page intercalated between the above discussed preface and the main body of the novel. Similarly to the preface, this generic positioning of the work immediately directs us to the question of its conventions: the Hungarian term "lányregény" - direct translation "girls' novel" - implies a story written for girls about girls, but as Annamária Sinka states, "the definition is problematic from several perspectives" $(2011,89)$. On the one hand, this difficulty arises from the fact that the subgenre enjoys very little recognition, a novel "built on easy-to-follow templates" $(2011,89)$; on the other, the term is often used to refer to works that have gained international recognition and have been part of the literary canon for a long time, such as the novels of the Brontë sisters or Jane Austen, their novels "mostly telling the story of young girls who do not always follow devotedly the recognized and accepted social norms of the Victorian age, and even though they may transgress the strict social norms and rules of feminine behavior, men play a major role in their destinies as marriage is the only road to the fulfillment of their love" (Sinka 2011, 90). Among the conventions of such "feminine" novels we may list the often stereotypical heroine within a girl-meets-boy scenario that - after the overcoming of diverse obstacles - leads to the "happily-ever-after" marriage; the exotic either in time or space or both as "integral to the genre" (Kaler and Rosemary 1999, 7), detailed presentation of the social milieu, the morals and communication patterns of such an environment, sentimentalism, as well as titles that often contain or consist of the heroine's name (remark made by Sinka [2011, 94] in her comparative study of Ildikó Lovas's The Spanish Bride and Charlotte Brontë's Jane Eyre). 


\section{Romance, Food and Female Subjectivity}

By the Black River starts and ends with scenes of a ball, an event framing the protagonist Anna Kevéer's story. In the opening chapter entitled "Arrival (from the end)" the omniscient narrative voice reveals to the reader that the scene is a remote Transylvanian village of troubled multinational history, a country manor the description of which occasions our introduction to the centuries-long history of the Hungarian aristocracy of this region. The time is the morning after the ball, when - after tangos, Sinatra's swings, waltzes and czardases - even Britney Spears has given way to silence. Thus we are transported into a world where the remote close-to-nature rural idyllic meets the upbeat cosmopolitan global culture, and where remnants of the memory of thirteenth century Hungarian kings, Transylvanian princes and the horrid legacy of communist totalitarianism merge into the present of our heroine. This duality and juxtaposition of history and the present, of the rural and the urban, of the local and the global characterizes the entire text, a fast-rhythm prose in which we follow Anna from her very fashionable career-woman and bride of a wealthy French artist life in Budapest, with frequent trips to Vienna, France or Switzerland, to her return to Transylvania, a space inseparably merged into her own and her family's history and that keeps invading her cosmopolitan existence.

Anna's story has all the ingredients of the typical romance: the stereotypical young woman, the mysterious new man suddenly stepping into her life in the figure of Gábor Kászoni (himself a descendant of Transylvanian and Indian aristocrats, brought up in the West just to return to the restituted but ruinous castle of his ancestors and continue the family's fight for the restitution of their estates nationalized by the communists) with whom Anna's fate changes drastically. The exoticism of the remote, rural space of Transylvania, the ruinous castles and burdened family histories also predestine the story for the genre. With Anna we also get a glimpse of Budapest life, the dressing- and behavioral codes of the Vienna ball season, as well as of the polar opposite of all these, the small Transylvanian village with its typical everyday life and larger than life characters whose verbal tics and archaic dialect, common sense and down-toearth mentality are source of lively scenes and much humour.

Where the romance would, however, conventionally end - the fabulous wedding with a charter train bringing the international guests to the event held in the barely renovated castle by candlelight - Ugron's novel continues and turns into much more than a template-generated love story with the obligatory happy end. As one of the reviewers of the novel has also remarked, it is after the wedding that the novel - and its heroine - undergo a metamorphosis: "From bored superwoman the protagonist turns into a flash-and-blood woman developing a very human interest in the culinary arts and it is just as human that 
from time to time she becomes the laughing stock of the Szekler village" (Fülöp 2011). The novel also subverts readers' expectations through its "minimalism," as another reviewer, Szalai puts it, stating that while the subtitle "Postmodern girls' novel about dreams, love, castles" sets up expectations, "a reader looking for feverish prose and emotional attunement will probably be disappointed" (2011). We do associate the tradition of the sentimental novel, sensibility and especially sentimentality with romance. The Dictionary of Literary Terms and Literary Theory states about the sentimental novel that it "attempts to show that effusive emotion was evidence of kindness and goodness" and that "it concentrated on the distresses of the virtuous and attempted to show that a sense of honour and moral behavior were justly rewarded" (Cuddon 1999, 809), while sensibility is defined as a term that became popular in the $18^{\text {th }}$ century "when it acquired the meaning of 'susceptibility to tender feelings'; thus a capacity [...] to identify with and respond to the sorrows of others - and to respond to the beautiful" (Cuddon 1999, 807). Sentimentality, on the other hand, appears as a pejorative term, with reference to literary works denoting "overmuch use of pathetic effects and attempt to arouse feeling by 'pathetic' indulgence" (Cuddon 1999, 809). Ugron's novel does not allow much association with the sentimental and neither with sentimentality, even the romantic love-story plotline lacks heightened emotional scenes and "pathos." Neither is moving back to Transylvania nor its motivation idealized as an emotional return to the roots. While there is some pastoral melancholy in the young aristocrats' leaving the cosmopolitan milieu of Budapest, Vienna, London or New York for the old-fashioned isolation of Transylvanian villages cut off from "civilization," the stated motives of their return are much more rational. ${ }^{8}$ Endre, Anna's cousin argues:

You should really be the one to understand that this is not some kind of fad; we were brought up in the belief that this [Transylvania] was Atlantis, the lost world; instead of fairy tales we listened open-mouthed to my grandfather's and Aunt Pólika's stories. Their Transylvania was the fairyland, and now here it is: Saint George, here you have your dragon, go fight it, win it back, build it up! Wouldn't it be crazy to stay instead in Budapest and try earn as much as possible for some multinational company? ( Ugron 2010, 106),

while Gábor's goal to get the family's forests back can also be traced back to financial considerations: he says he would not have been able to earn as much in London as the forests will be worth, not even by the time he was forty.

The element that replaces and goes against such sentimentalism is humour. The novel abounds in scenes mixing humour and self-irony that turn the everyday situations of the cosmopolitan youth in the remote Szekler village into high 
comedy - from the first horse-ride on the back of the neighbour's horse used to pulling carts rather than carry countesses on its back to Anna not knowing where to look for the green beans in the garden or trying to chop wood. Hilariously funny are also their attempts to save the rose garden from the sheep herd roaming around the park of the castle or chasing out horses from the newly renovated hall and the garden at night-time under the surprised eyes of their bed-and-breakfast's first guests, English diplomats whom they have to convince the next morning that the barely dressed young count's midnight running around is not regular part of the tourist program they offer their guests. The realistic but still humorous social portrait of the village with its typical characters, customs, language and mentality - with Aunt Zsófika emerging as the uncrowned queen of social relations and of the news possessing the almost mystical capacity of knowing everything before anybody else without leaving her house - is constantly juxtaposed with the young couple's and their circle's urban and international attitude and mentality. A farther source of verbal humour is the contrast between the often archaic dialect of the locals contrasted with Gábor's Hungarian that he speaks with an accent mixed with German and English expressions. The contrast of the two worlds becomes even more emphatic through the wedding party ambushing the village and the guests of the bed-and-breakfast ranging from diplomats and politicians to Spaniards with their special ham (that they also offer to the housekeeper who thinks they want to poison her) and the international participants of an old-timer rally from London to Transylvania for whom they throw a Ball of Vampires to the shock of the entire village.

History also appears masked in humour: the terrors of the communist regime as well as the horrific legacy of totalitarianism are depicted with the wit and elegance of the embedded anecdotes and the black humour of Gábor's first period spent in the village, like his memories of his first New Year's Eve in the castle that at that time was still functioning as a mental institution. The nested anecdotes ingeniously create a whole new layer of the literary universe with eccentric and legendary figures of the family history. Through these embedded texts a lost, destroyed culture and lifestyle comes to the surface with an elegance, manners and morals that belong to a past era and that evoke both the gentry-novels of the early twentieth century Hungarian literature and the tradition of the comedy of manners.

Among the generic conventions of romances critics often mention their euphemistic language and phrasing - especially regarding sexuality. Ugron's novel abides by this convention; however, the body and its presence and importance appear emphatically through the motif of food and cooking. Novels celebrating food, the sensuousness of eating, featuring dinner parties or recipes, with characters finding an outlet for their creativity in the culinary arts or in setting the scene for fabulous feasts have been numerous: from Kate Chopin's Edna in The 
Awakening throwing her luxurious birthday dinner almost as a manifesto of her individuality and liberation to Mrs. Dalloway's busy kitchen with "plates, saucepans, cullenders, frying-pans, chicken in aspic, ice-cream freezers, pared crusts of bread, lemons, soup tureens, and pudding basins" (Woolf 1996, 181-182), from Liz in Elizabeth Gilbert's Eat, Pray, Love absorbed in the beauty and sensuality of Italian food and Italian language to Marsha Mehran's Pomegranate Soup with each chapter opening with a recipe of exotic Iranian dishes such as "Fesenjoon" or "Elephant ears." Still, up to the contemporary interest in all things culinary when TV programs are saturated with cooking shows, cooking contests and reality shows, and when bookstores offer every imaginable kind of recipe collection and books related to every aspect of preparing and consuming food, food and the art of cooking was for a long time perceived as a trivial subject. As Aoyama Tomoko states in her study "Literary Daughters' Recipes. Food and Female Subjectivity in the Writings of Mori Mari and Koda Aya," referring to the theoretical work of Deborah Lupton, there can be perceived "a historical neglect, disgust for and fear of food and eating, based on the view that they are banal, feminine, embodied, impure, unclean, and uncivilized" $(2000,95)$. However, she also states that food and activities related to its preparation, perception and consumption "cover a variety of areas and dimensions concrete or abstract - not merely inter-personal relations (between family members, for example), but also relations between nature and culture, the physical and spiritual or metaphysical, as well as the individual and society, fact and fiction, and production and reception” (2000, 91).

In By the Black River Anna's whole journey from her life in Budapest to finding her place (even if this finding of a place of one's own is a continuous process of constant destabilization and return to balance) in the remote Kézdiszentimre is linked to food: from dinners with friends and family to her wedding menu and starting her "awakening" in the kitchen of the renovated castle. Her passion for food develops slowly and out of sheer necessity: as the "young countess" of the dominion she is expected to reign over domestic aspects of their lives including what dishes to serve to their guests and how she wants the pork to be processed. And gradually this becomes the "support" that the author confesses to have been looking for when she herself moved to Transylvania, a search mirrored in her character's fate. Cooking, different cuisines from the old aristocratic to typical Szekler dishes and the demands of their guests, link her to the women of the village, and gradually - thanks to the old recipes of her grandmother - she becomes an authority in matters of innovative dishes. Cooking also becomes a means of self-expression and creativity and a source of aesthetic pleasure in her life. In this sense gastronomy and food turn into the domain of the formation and evocation of her subjectivity - understood as an entity in constant shifting and transformation rather than a stiffened and stable "identity." She becomes an active subject creating her own "culinary narrative" in a rather postmodern pastiche 
manner: her passion for food and for the beauty, challenge and creativity involved in cooking is a legacy of her "foremothers" that she discovers and revives in her own story. It is the old recipe collection of her grandmother that initiates her immersion into the art, and which offers her a link to her and her family's past as well as to her present (the village) and her future (a new livelihood, for example, through the bed-and-breakfast). This is also the starting point towards expressing her own subjectivity understood not in the binary opposition that the very topic of food and cooking as "feminine" domains might suggest: of male-female, active-passive, subject_object(ified). Much rather, as Nóra Séllei suggests, a process through which the female becomes an active/speaking subject $(2007,9)$. Anna's subjectivity is constructed through the evocation of the past that at the beginning seems to overwhelm her and that crashes into her life unexpectedly and uninvited, a past that in Anna's mind is always closely connected to food: "For a long time Anna has felt the same way about Transylvania as she felt about stuffed cabbage. [...] She would eat it for days, but only once a year, at Christmas. [...] Without cabbage there would be no Christmas and life would not be worth living. Once a year, but that's a must" (Ugron 2010, 15).

"Food is also a subject that is strongly associated with memories and nostalgia," Tomoko states $(2000,93)$. It is not accidental then that Anna's personal memories, her family's recollections and the embedded anecdotes are so often stories related to food and culinary experiences, even when they tell about the times of the Ceausescu regime when there was nothing to eat. However, this does not lead to Anna simply copying the past. Much rather, to use Tomoko's phrasing, she develops "her own 'recipe' for evoking female subjectivity" $(2000,96)$ by merging her family’s collective memory with local customs and Aunt Zsófika's mastery in everything human, that is also cooking, and her own international experiences. If we consider Séllei's argument that "the subject is created through semiotic signsystems, often through and in language" $(2007,13)$, we may come to conclude that in Anna's case cooking and food constitute this system of signs in and through which her subjectivity manifests herself and where she finds her place, as one of the closing paragraphs of the novel suggests:

We managed to throw the ball after all.

Ducks, donkeys, children chasing each other and the chickens in the dusty streets, a stream sluggishly flowing among the multicolored Saxon peasant houses, and arriving in the dust of the late summer the party in evening gowns and tuxedos. Marvelous pink lamb chops, tarragon chicken, aubergine cream - a must in Transylvania, buffalo mozzarella from the nearby Köhalom, truffle ravioli, and by the time all the guests found their places at the tables, on the axis of the French garden's geometrical center the sun went down [...]. (Ugron 2010, 293) 


\section{The Epistolary Novel and Authorial Female Subjectivity}

When talking about blurred genres, a particular representative is Ugron's second novel, entitled Szerelemféltók [The A-B Dialogue], which combines the genres of the epistolary and the sentimental novel, literary sketch, short story, folk songs, plays, even legends infusing and alloying them in a postmodern jar by fragmentation, intertextuality, temporal disjunction and mostly by presenting the subject in its processual nature, continuously built and deconstructed by different instances of the narrative voices.

At first glance The A-B Dialogue is an epistolary novel, revived or even improved by certain techniques. It is an interesting and at the same time odd choice of the authors, as the epistolary genre is not a fashionable one nowadays. In fact, after the eighteenth century there were no memorable epistolary novels written in Hungarian and Transylvanian literature and after the nineteenth century it does not play a significant role in universal literature either. Its flourishing in a certain period - eighteenth and early nineteenth centuries - is due to the fact that the omniscient narrator, capable of diving into his characters' minds and feelings had not been born yet. Since first-person narrative apparently certifies the verisimilitude of the created personality, the sentimental or epistolary novels present themselves as inner monologues. From this perspective, by the exclusiveness of the inner point of view the epistolary and sentimental novels of the eighteenth and early nineteenth centuries represented an opening towards Romanticism, which praised lyricism and subjectivity (Tapodi 2008, 239).

Hungarian literature links the genre of epistolary novel to the name of the nobleman Kelemen Mikes, exiled to Turkey in the eighteenth century, who - living in Constantinople for over forty years - wrote two hundred and seven letters to an imaginary aunt. Törökországi Levelek [Letters from Turkey] (1794) includes facts and feelings related to the life of the exiled and it offers valuable historical background information on current events taking place in the Turkey of those times. Another classic example for sentimental and epistolary novel in Hungarian literature is signed by József Kármán entitled Fanni hagyományai [Fanni’s Testament] (1794), which according to the author himself, presents "the story of a beautiful soul and sensitive heart" ("Fanni") that unfolds from the letters and the diary of the heroine, Fanni, who eventually dies of broken heart. The author follows Goethe's lead in The Sorrows of Young Werther (1774) when declaring himself a simple collector, editor, who gathers and publishes texts authored by Fanni.

The A-B Dialogue fits in the genre of the epistolary novel, but in a reinvented, enriched form: unlike in a traditional epistolary novel, the letters are not the projections of the same mind of the one and only author who creates his/her narrators as the idea of a modern epistolary novel came up during the authors' actual correspondence: "We slipped into the two characters and continued to 
write to each other until the letters and stories fit together" - says Ugron (Moly 2016). According to Meskó,

the novel deals with the unspoken past of Hungarian society. This past consists of unspoken familial and individual stories. People used to cope with everyday issues by writing letters and diaries. The correspondence of our heroes is an attempt to confront the past and themselves. This way they help each other express their untold thoughts. (Moly 2016)

Structurally, the novel contains thirty-six letters, seventeen written by Anna, nineteen by B. and twenty-seven embedded texts among which there are short stories, sketches and plays. Every chapter is marked by the name of the month, for over a year, from January to January and begins with a love song/ballad of Szekler folklore published in the collection of János Kriza's Wild Roses. Collection of Szekler Popular Poetry (1863). The nested narratives follow the letters and are authored by the correspondents themselves. However, not every letter is accompanied by such an addition. The closing part of the book is the legend of Saint Elisabeth, a saint that apparently occurs and plays a role in both narrators' lives.

The initiative belongs to Anna, who suffering from broken heart, similarly to a crime of opportunity, chooses a man from her past, B., to reconnect with after ten years. By taking the initiative, Anna emerges as the feminine subject, active both factually and linguistically, who chooses to start the discourse, not just respond. She does not motivate her decision to write and neither does she explain why her choice has fallen on B. as her intended correspondent with anything else but an old photograph: "I don't know why I am sending this [a photograph taken ten years earlier] to You now, do not look for explanations, really, there is no explicit intention in it. I was just wrapping up some stuff, it came up, I pass it through” (Ugron and Meskó 2011, 5).

The female subject does no longer occupy a secondary, passive and submissive position, which does not speak unless spoken to. Unlike Virginia Woolf's female subject in Three Guineas, who starts to write and through writing construct her own subjectivity as a response to certain letters (Séllei 2007, 316), Ugron’s Anna does not display the classic patriarchal subordination scheme. Nevertheless, her initiative comes after suffering a trauma, as we are to find out later, and she seems to have reached a point from where she is simply forced to reinvent herself, to make order in her life lest to die like her mother or worse, lest to live a disturbed life with too many problems left open. B. seems to represent one of these open issues, an acquaintance from ten years ago. It seems that the two characters share a past and during their correspondence they are trying to get some sort of closure but they also wish to find out if they have a future together. Every text that follows the letters is about Anna and B., who appear as different occurrences of the 
same subjects, Anna and B., and almost every story ends with the uncontestable knowledge of the impossibility of their relationship. Every instance created by the writing parties shuts down a certain situation, either one of them dies or marries another, leaves or cheats on the other. This parallelism or multiplication of the presented subjectivities is hinted at by Ugron herself when she states about the novel: "It is not a romance in the classical sense. It is the story of lots of loves and lots of almost loves" (Moly 2016).

Anna's subjectivity is constructed from the instances of Anna that appear within the short stories, sketches and plays, projected either by the letter-writer Anna or by her correspondent friend, B. These stories are displayed without any chronological order, we see the child Anna, lingering on her mother after we have seen her mother dying on an icy road in Transylvania. We see the brown-haired young woman who chooses to terminate her pregnancy and afterwards comes the girl who decides to keep her baby, to finally see a self-convicted man who has never forgiven himself for suggesting his girlfriend to terminate her pregnancy which, however, she holds on to in spite of being alone, but unfortunately both mother and baby die in the eighth month.

The female characters of the embedded stories show Anna as a child, a mistress, a wanted but untouchable, almost idealistic woman, a cousin who must not love her male cousin, a young girl in the Angels' land who has killed herself because her mother had forbidden her to love her brother, a deported Jewish girl, a boring, old partner of a man, a young, restless girl always on the run with her mother's suitcases, a wife cheated on by her husband with her friend, a wife, cheating on her husband, a femme fatale, a spy, the self-destructive or the pregnant Anna. These instances contribute to the configuration of the female subject, the subject that is not a fixed entity but under continuous construction and in constant shifting from one position to the other. Both narrators' subjectivities are flexible and malleable, they shift from one position to the other according to the given situations they inscribe themselves into. These constantly changing masks that the narrators slip into that may represent polar opposites of each other or seemingly head towards different directions lead to the construction of their incoherent subjectivites (Hall 1992, 598).

This incoherence is shown best by the narrators' bouncing from objectivity to subjectivity, from passive to active displayed through the Annas and B.-s they create, which at the same time constitute the foundation of the discourse of their own subjectivities. Anna's B. is either extremely weak, incapable of getting in touch with the girl he likes, or highly impulsive: in the shape of B. she kills her Anna for ending their relationship. B. senses that Anna needs to see herself as in a kaleidoscope, so he creates a wider spectrum of Annas: first of all, he rewrites the first letter the way he thinks Anna should have written it, then in the short story entitled The Ad, written by B., Anna turns to a professional service to help her 
accept and love herself, in The Coffee House also authored by B., there are present two instances of Anna at the same time, a young woman, girlfriend of B., and an older wife, cheating on her husband with B., both called Anna, Anna the Jew and B. the one who participates at the Jews' extermination in Porcinello, and so forth.

In this sense the novel displays the postmodern concept of the subject where coherence and stability has become impossible. The postmodern subject does not even attempt to reach coherence, unity and stability; on the contrary, it finds its balance in malleability. The backbone of the subject is not ensured by the attempt of guiding all the instances of the subject in the same direction, but by identifying these appearances, letting them follow their own course through and in writing. Anna is in a constant quest of a self, her life is deconstructed piece by piece and by inscribing herself in the discourse she is reinventing her past and present. Unlike J.M. Coetzee's Susan Barton in Foe (1986), Anna finds her own voice, she does not need an outer force, a man, an author to write her story, to locate her in a discourse.

The weak and suffering Anna builds herself up through the letters, she creates an Anna capable of developing to be able to deal with the psychological issues caused by her mother's early death, reaching the stage of recognizing the resemblance with her mother but refusing to be her mother and she grows to make decisions of her own. On the other hand, there are Annas who do not manage to cope with life and they commit suicide. Anna needs to observe both her suicidal and her self-assured instances at the same time and this kind of rupture is possible only in the realm of the imaginary, in literature. From the perspective of the female subject, under construction, it becomes clear early in the novel that while putting the pieces of herself together the medium of letters is the only way of interaction with B., regardless of how much he wishes to meet her and connect in the real world. She sets the rules and the means of communication, she is in control, she allows herself a break when not being in the mood for writing and she does not accept anything from B. except his writing.

The act of writing as the single way of communication between the characters, since they disregard all other means of contact of the modern world, such as phone or e-mails, is put upon a pedestal, almost sanctified: B. confesses that he writes his letters on a certain kind of paper, with a certain pen and ink, a pen that he does not use for anything else, but to write to Anna. The quintessence of writing is to explore the abysses of the past and those of the mind of the two characters, and to observe, to reinvent themselves in every possible way. Their dialogue sets the frame for this quest, a dialogue that is realized on the level of the letters and on the level of the stories, where Anna and B. confront their common past and themselves. Anna's inscription in the discourse has to happen because she feels the urge of constituting herself as a subject and she invites B. to be a part of this process. By creating several Annas, both Anna and B. continuously 
generate and regenerate her as a subject, until she feels secure enough to accept that her feminine subjectivity is not a stable, fixed or predetermined one, but in continuous formation.

In writing, the instances of the narrators get to be happy together, even marry and "plant trees," that is have children. In writing and only in writing gets the sentimental reader to see a happy ending, the two characters together after figuring out their past issues, their questions to each other and their fears. The letter-writer Anna and B. meet eventually, when Anna wants to meet, they share a nice dinner and Anna informs B. about her engagement with Moritz, her colleague from the restaurant in Vienna, shaking this way the ground under B.'s feet. It seems that she has used B. to help her through her darkest hours and then, after finding her joy in work and a fiancée, and after coming to terms with her multiple subject positions, the constant shifting and the responsibility which goes together with an identity conceptualized in terms of such a destabilized subjectivity, she simply casts him away. However, in the process of Anna's formation B. has constituted himself also by looking back, finishing up and, of course, by writing.

What should I write to you? This is the last letter of the year. It is like everything has happened to me this year that could happen to a man. A man without a family yet.

I celebrated our meeting. I didn't know how to prepare my heart for it. I didn't expect anything, but it was there inside of me: this is going to be the last moment together or it is the beginning of a new life. [....]

And see how tricky life is? After all these, you spill the beans about Moritz... I felt like I was hit by lightning. For a moment I thought I would fall off the chair. For minutes afterwards I only focused on you not to notice what was going on inside of me. [...] What is this? If the incident by the bench calmed me down and I saw us clearly, then what was this lightning... Pictures came and flew away. The film of this year flashed before my eyes and suddenly all the tension was gone. I said to myself the very sentence you had also written. This year has been one of the best gifts I have ever received. I got it from you. Together we grew capable of new beginnings. Thank you for that. (Ugron and Meskó 2011, 317)

These final words show that the main reason of writing is not to present the everyday life of a certain group of people or a place and culture, as it is in the case of Letters from Turkey, nor is it to display the inner life of a character who suffers from love, like Fanni, or the society and the way it deals with young, inexperienced servant girls approached by their devious masters, as in the case of Richardson's Pamela or Virtue Rewarded (1740). The A-B Dialogue, although it bears sentimental and romantic features, emphasizes writing as the act of 
communication and - more importantly - that of creating, building the acting subject within the dialogue. If Anna had been Fanni, she would have said yes to meeting B. at his first invitation, she would have found love in him and would have felt safe and stable, or in case of her love not returned, she would have written about it with the necessary pathos of sentimentalism. Anna does not need another person to reach a sense of security. Neither does she need someone to cry to. Nor would a monologue, a diary or an imaginary addressee serve her purposes. She needs a counterpart to talk to, a dialogue, a reflected Anna in order to undergo the process of inventing and reinventing, generating and regenerating, constructing and reconstructing her own feminine subjectivity.

\section{Historical Romance, the Picara and Female Subjectivity}

"One of the most conspicuous developments of the Hungarian fiction of recent years has been the evocation of the 'historical novel'” - Szirák writes $(2001,47)$. Historical romances such as Jókai's or Gárdonyi's works have always been highly popular, providing a generic and textual heritage that contemporary authors may build on. Of course, novelists attempting a revival of the genre have devised alternative techniques and perspectives in their narratives of historical events. Discussing János Háy's Dzsigerdilen, Szirák talks about the new historical novel as "the 'adventure' of merging fiction with supposed reality" $(2001,47)$. Ugron has also stated in an interview:

Philippa Gregory argues that historians also write fiction but without the liberties of a novelist. And if you think about it, it's true. We don't know anything about the way people used to live, think or what motivated their choices. The historian says: this is what we know, but we do not know the rest. I have the freedom to imagine the rest. (Bookline 2016)

The Úrasszonyok [Splendour] trilogy continues the legacy of nineteenth century Hungarian historiographic fiction, what is even more, the author has chosen to represent an era that constituted the subject of one of the great forefathers, Zsigmond Móricz, in his Transylvania trilogy, one of the most turbulent and unstable periods of Central-Eastern Europe - the first half of the seventeenth century. Where it subverts the heritage and alters the perspective - beyond the fact that Ugron enters a literary domain traditionally dominated by male novelists - is that this bloody and war-stricken historical era is depicted from the point of view and through the eyes and destinies of the women of those times.

Discussing the possibilities and also the issues the new (postmodern) historical novel faces, Sándor Hites argues that these contemporary works distinguish 
themselves from the old historical novel by characteristics such as the multiplicity of perspectives, the emphatic control and intrusive presence of the narrator in the narration, fragmentation and mosaic-like construction, the polyphony of discourses, the deconstruction of chronology, non-authentic depiction, the heightened role of the imaginary, and the perception of history as a construct (2003, 38-45). In this sense, historical novels become - or have always been to a certain extent - something other than the "depiction" or "representation" of historical events - despite the strongest demand for credibility and authenticity. They are much rather texts experimenting with their own genre, the combinatory possibilities of their generic constituents and of language in order to create meaning (see Hites 2003), as well as to represent the potential of the genre and thus of language to express the processual nature of subjectivity. Ugron's statement that "in my reading this book [The Palatine's Women; but we may enlarge the field to all four of her novels] depicts a woman's destiny, it presents the timeless issues and dynamics of female relations and female-male relationships" (Bookline 2016) links her work to the above arguments.

Erdélyi menyegzố [Splendour] follows - in a more or less chronological order - the destiny of the infamous Anna Báthory, whose fate is inseparably interwoven with that of her dynasty (she being one of the last descendants of the Báthory house that yielded kings and princes and international scandals and is now on the verge of disappearing from history) and of her country at that time divided into three and devastated by constant regional wars and the twofold pressure of being trapped between the Habsburg and Ottoman geopolitical ambitions. Her journey leads her from being the celebrated beauty of her brother's court and a wife to being twice widowed, on trial for witchcraft, immoral behaviour and other atrocious charges, tortured and dispossessed of all the fabulous estates that she had owned. She manages to escape with the help of Miklós Eszterházy - to whom she is linked for life by a mutual love that is never to be fulfilled - and this is when her travels start. Accompanied by her Chinese slave/servant Lin - who throughout the novels functions as a surrogate mother, girlfriend, tutor and protector/provider - she travels to Warsaw, and then in the entourage of the Polish crown prince to Brussels and Venice, where the first volume leaves her. The last chapter of Splendour consists of a firstperson narrative, a diary entry signed by Krisztina Eszterházy in 1636, eleven years after we leave Anna in Venice, from which we learn that our now refugeseeking wonderer has just arrived to the estates of her childhood protégée Krisztina, now wife of Miklós Eszterházy:

She [Anna] arrived to Fraknó two days ago. She came by a simple coach, barely bringing anything with her but a chest. She came alone, no escort. Her gown worn, her steps painful. And yet, she seemed to be glowing. 
She did not ask for anything. She did not beg. And neither was she haughty in her wretchedness. When asked how she had been, where she had come from, which way she was going, she smiled.

- Well, could I ever know where I was to go? But now finally I can go wherever I want, wherever I desire. I have laid my burdens. I have paid the price. (Ugron 2013a, 350)

A nádor asszonyai [The Palatine's Women] is structured differently, if possible, even more focused on the female characters. Chronology is broken and several voices tell the stories of women through whom an alternative history of the seventeenth century is constructed. The different chapters - in relativized order - cover the period from 1624 to 1645, and operate with different narrative perspectives. While the first chapter picks up the storyline in the same voice Krisztina Eszterházy's - as the first volume ended, it jumps back in time to 1624, the year Miklós Eszterházy was elected Palatine of Hungary. Certain chapters are told from an omniscient narrator's point of view, others from a limited thirdperson perspective, focusing on one or the other female character such as Erzsébet Czobor, Kata Várday, Katherine of Brandenburg or Anna Báthory, and in yet again others we hear the voice of the women themselves, Krisztina, Lin or Anna. The link among them is the figure of Anna Báthory who by this time has become a true representative of the picara: travelling from one royal court to the other across Europe she is somewhat similar to the famous female spies and double agents of history (like Mata Hari or Violette Szabó). As József Sántha remarks in his review of the volume, "Anna has become a classic adventuress and the novel a historical adventure story" (2015).

"The picara occupies a unique position in the history of literature. She is not glorified as an angel or a mother figure, nor can a neat label such as sinner, murderess or evil married woman circumscribe her personality" (Daghistany 1977, 51). A similar definition comes from Anne Kaler:

In literature the figure of the picara is an elusive and neglected one [...] often mistaken for the feminine counterpart of the picaro [...] the picara has her own identity. Yet critics to date have ignored or misread her presence in the tapestry. They condemn her as a wanton; they revile her as a sinner; they dislike her as a woman. Why are their criticisms so harsh? Perhaps it is that the distinguishing feature of her tapestried figure is [...] her autonomy. $(1991,1)$

Kaler's above quoted introduction to her volume The Picara. From Hera to Fantasy Heroine serves well a discussion of Anna Báthory's character. Within the tapestry of the multiple narrative perspectives and voices of the Splendour trilogy's two published volumes, in the disorderly chronology of narration (often 
one event being presented from multiple points of view - for example, we learn about Eszterházy's election to Palatine from his wife's words, from the perspective of his powerful and always plotting mother-in-law Kata Várday, as well as from Eszterházy's letter; or Anna's time spent in Belgrade from both her own and from Lin's description) Anna emerges as "an archetypal pattern of autonomy" (Kaler 1991, 2). She weaves her complex and always shifting subjectivity by masquerading from her early childhood to the very end: as Krisztina's surrogate mother, as obedient servant of her prince brother and of their family legacy, as an eastern diplomat's mysterious and enchanting wife in order to be able to attend a ball without being recognized as Anna Báthory, as seductively undressing temptress of her second husband, Zsigmond Jósika. She actually assumes a pseudonym while in the court of the Polish crown prince and from then on the Transylvanian princess keeps resurfacing in the different royal houses of Europe in the disguise of the "Polish woman," Countess Smokowska.

"The picara's mentor is her confidante, her magical weapons are her wit and sexuality, [...] her adventures are her wonderings" - Kaler argues, she is someone "trapped in a survival mode, struggling for [...] autonomy" $(1991,2)$. Anna is a woman of times of war, high treason, conspiracies and murders, of dynasties disappearing and new ones being born, an era when it was obvious and manifest that the personal was always also political and public. Her sole companion and mentor is Lin, her means of survival are her wit and her beauty, and her ability to tell stories. She possesses a large stock of stories to tell from her own family history and experiences to all the exciting stories Lin told her about faraway places, people and customs. She gets by, basically she survives - just like Scheherazade in One Thousand and One Nights - due to her marvelous skills as a storyteller, entertaining the Polish, Belgian, Habsburg and Transylvanian courts as well as the Turkish harem and the Sultana.

Her love affair with Miklós Eszterházy adds a further layer to her portrait and also to the novel. As Sántha remarks, “in Miklós Eszterházy and Anna Báthory’s sensual but emotionally always restrained relationship we may recognize the heroes of Sentimental Education with their unfailingly passionate affections which, however, never transgress social norms" (2015). Thus, just like the picara, she does not become a typical romance heroine who would need to capture a man to marry in order to fulfil her role as a woman.

Where, then, lies the source of her autonomy? In times and places like the early seventeenth century Transylvania, within an emphatically patriarchal order and a male dominated world, how can women obtain autonomy? This question becomes even more important in view of the fact that beyond the picara Anna Báthory, the novels present a large scale of powerful women, of both high and the lowest social standing. Though they are "rarely allowed to decide in matters of their own fate, they manage huge estates and defend fortresses" (Ugron in 
Bookline 2016), they rule countries and ultimately they are the ones who decide who of the men around them would serve their and their families' interests best, thus whom to promote and aid into political positions. We meet Kata Várday endowed with marvelous social and political networking skills who seems to be pulling all the strings from the background and who also emerges as a patron of talented young men financing their education in order for them later to serve her own interests and purposes. Or there is Erzsébet Czobor, who manages one of the largest estates of the country and fulfils the position of Lord Lieutenant of two counties. In Brussels and Istanbul we meet women ruling their empires and centralizing all the power associated - especially in those times - with men into their own hands. Lin stands for another type of female empowerment: the former slave, herself with an adventurous life that led her from China all through Europe to finally settle with Anna, gains control through knowledge and skill and the magic people associate with her. ${ }^{9}$ And they do all this being widows.

Asked what interested her in these women's fates, Ugron stated:

Mostly this duality [of being empowered in an age that deprived women of any power]. And the fact that within such a rigid system which from a superficial perspective and from the point of view of its rules and norms was so emphatically a men's world, there were women who were able to enforce their own will for their own or their loved ones' sake, or in the service of their community or country. (Bookline 2016)

In attempting an answer to the above question we turn to Séllei's definition of subjectivity and its relation to power. Relying on Michel Foucault's arguments in "The Subject and Power," Séllei states that subjectivity is a cultural construct, a constantly shifting position inscribed by the discourses of power $(2007,10) .^{10}$ Power in this sense is a system of discourses which are not necessarily in harmony with each other. Therefore, power comes from multiple sources and its practices are not uniform and homogenous (Séllei 2007, 11). In Anna Báthory's time the patriarchal system is opened up exactly by this constant disharmony and diffusion of power, Transylvania being torn between the Habsburg and Ottoman demands, devastated by wars and constant imbalance on grounds of religious disputes and men's political ambitions. Séllei further argues: "the disharmonizing elements of dominant discoursive practices create rifts, fissures and ruptures that open up the system and create the opportunity for the formation and acceptance of new, alternative and subversive subject positions" $(2007,11)$. The ruptures and rifts

9 The magical and mysterious are also present in Anna's fate - in the form of the Báthory rings and Báthory curse, not to mention her kinship with the internationally infamous Erzsébet Báthory.

10 Foucault differentiates between power-relations and totalitarian dictatorships - where what are formed are not subjects but slaves. 
created by the above mentioned instability of power relations and dominant discourses in Transylvania - and Central-Eastern Europe - of the first half of the seventeenth century constitute the spaces where women like Kata Várday, Katherine of Brandenburg, Sultana Kösem and Anna Báthory manifest their subjectivity in a subversive practice in order to survive and - if possible - manipulate the system. Through their figures the author of Splendour-herself a woman constantly shifting among multiple subject positions - revitalizes the historical romance genre and opens it up to incorporate the female narrative of history.

\section{Conclusion}

In an essay entitled “Do Postmodern Genres Exist?” Ralph Cohen offers an overview of contemporary theories on the issue of genre and concludes that although "[p]ostmodern critics have sought to do without a genre theory" $(2000,295)$,

[i]f we seek to understand the historical recurrence of certain kinds of writing, the rejection or abandonment of other kinds, genre theory provides the most adequate procedure for this inquiry. If we wish to analyze an individual text, genre theory provides a knowledge of its constituents and how they combine. Not only do these actions recognize the value of a genre theory in analyzing modernist writing, but they demonstrate that postmodern theorists, critics, authors and readers inevitably use the language of genre theory even as they seek to deny its usefulness. $(2000,306-307)$

The present study aimed at analyzing how genres such as the romance, the epistolary novel and the historical romance may take on new attires to "house" the representation of the constantly shifting subjectivity, specifically the construction of the female subject. We have demonstrated that by altering the conventions, non-linear narration, the insertion into the narrative of other texts (recipes, anecdotes, letters, sketches, folk songs, etc.), through the blurring of borders among different genres and the mixing of their constituents, and thus subverting readers' expectations, Ugron succeeds in creating specific female narratives in the various power discourses she depicts.

In order to position themselves as subjects, Ugron's Annas (and several of the other female characters in her novels) must find the fissures in the system of power and the appropriate sign-system to inscribe themselves into the discourse. In the case of Anna Kevéer (By the Black River) this semiotic sign-system is gastronomy: in her attempt to connect with the past she finds cooking as the sole link that gathers all her instances - the newly-wed wife, the descendant of aristocrats, the cosmopolitan, the local celebrity, the lady of the house - and she 
uses it to express her female subjectivity. The correspondent Anna in The $A-B$ Dialogue uses letters, a male addressee and short stories, sketches, plays, legends to overthrow established power relations and affirm her female subjectivity, conveyed by the multiple reflections of her self. Anna Báthory (Splendour, The Palatine's Women), the hunted and wanted woman, embodies the figure of the picara which finally gives her full freedom of choice and autonomy. Having these instruments at hand, she inscribes herself as subject in the male-dominated discourse of history.

A sophomoric reader would certainly stop at the genres and classify Ugron's novels according to their recognizable conventions: aristocracy, balls, weddings and love suit romance, letters suit the epistolary novel, while war, royal courts, conspiracies, sultanas and princesses suit the historical romance; and he/she would never reach beyond. However, in Zsolna Ugron's novels genres constitute the means, not the goal; they appear as the author's own semiotic system, the new attire she gives to old genres best shown by the ease with which she plays with them in order to create l'ecriture feminine.

\section{Works Cited}

Bárány, Tibor. 2011. “Szépirodalom vs. lektűr.” [“Literature vs. popular fiction.”] Holmi, Febr. http://www.holmi.org/2011/02/barany-tibor-szepirodalom-vslektur (Last accessed 30 March 2016)

Benedek, Leila. 2014. Interview with Zsolna Ugron. "Ugron Zsolna: Bánt, hogy a kortárs magyar irodalom nem fogad be.” [“Zsolna Ugron: I Am Sorry that Contemporary Hungarian Literature Does Not Accept Me.”] http://librarius. hu/2014/11/23/ugron-zsolna-bant-hogy-kortars-magyar-irodalom-nem-vesz/ (Last accessed 30 March 2016)

Bookline Interview with Zsolna Ugron. 2016. http://bookline.ro/news/news. action?id=11968 (Last accessed 02 April 2016)

Cohen, Ralph. 2000. “Do Postmodern Genres Exist?” In Postmodern Literary Theory. An Anthology, ed. Niall Lucy, 293-309. Malden: Blackwell.

Cuddon, J. A. 1999. Dictionary of Literary Terms and Literary Theory. London: Penguin.

Daghistany, Ann. 1977. “The Picara Nature.” Women's Studies vol. 4 no. 1: 51-66. Foucault, Michel. 1982. "The Subject and Power." In Beyond Structuralism and Hermeneutics, 208-226. Chicago: University of Chicago Press.

Fülöp, Noémi. 2011. "Úrilányok Erdélyben: posztmodern (?), lányregény (?).” ["Young Ladies in Transylvania: Postmodern (?) Girls’ Novel (?).”] http://multikult.transindex.ro/?cikk=13688 (Last accessed 31 March 2016) 
Geertz, Clifford. 1980. "Blurred Genres: The Refiguration of Social Thought.” The American Scholar vol. 49 no. 2: 165-179.

Hall, Stuart. 1992. "The Question of Cultural Identity." In Modernity and Its Futures, eds. Stuart Hall, David Held and Tony McGrew, 273-326. Cambridge: Open University Press. http://faculty.georgetown.edu/irvinem/theory/HallIdentity-Modernity-1.pdf (Last accessed 31 March 2016)

Hites, Sándor. 2003. "A múfaji önazonosságról.” [“About Generic Identity.”] In Az elbeszélés módozatai [Modalities of Narration], eds. Ildikó Józan, Ernő Kulcsár Szabó and Mihály Szegedy-Maszák, 28-62. Budapest: Osiris.

Kaler, Anne K. 1991. The Picara. From Hera to Fantasy Heroine. Bowling Green: Bowling Green State University Popular Press.

Kaler, Anne K. and Rosemary E. Johnson-Kurek, eds. 1999. Romantic Conventions. Bowling Green: Bowling Green State University Popular Press.

Kármán, József. 1794. Fanni hagyományai. [Fanni’s Testament.] http://mek.oszk.hu/00700/00722/00722.pdf (Last accessed 03 April 2016)

Laik, Eszter. 2011. "Modern mágnások - Ugron Zsolna Úrilányok Erdélyben címú regényérôl." ["Modern Magnates - On Zsolna Ugron’s novel Young Ladies in Transylvania."] In Irodalmi Jelen 6 Febr. http://www.irodalmijelen. hu/05242013-1423/modern-magnasok-ugron-zsolna-urilanyok-erdelybencimu-regenyerol (Last accessed 31 March 2016)

Lewis, Barry. 2003. "Postmodernism and Literature." In The Routledge Companion to Postmodernism, ed. Stuart Sim, 121-133. London and New York: Routledge.

Mehran, Marsha. 2006. Pomegranate Soup. New York: Random House.

Mikes, Kelemen. 2000. Törökországi levelek. [Letters from Turkey.] Budapest: Osiris.

Moise, Gabriella. 2007. "A nőfejú kígyó Édenében.” ["In the Eden of the WomanHeaded Snake."] In A nô mint szubjektum - a nói szubjektum [The Female as Subject - The Feminine Subject], ed. Nóra Séllei, 216-227. Debrecen: Debrecen University Press.

Moly. 2016. Szerelemféltók. [The A - B Dialogue.] http://moly.hu/konyvek/ugronzsolna-mesko-zsolt-szerelemfeltok (Last accessed 03 April 2016)

Palkó, Gábor. 2003. "A műfaj mint médium (?) Közvetítés és közvetettség a Fancsikó és Pintában." [Genre as medium (?) Mediation and Mediatedness in Fancsikó and Pinta."] In Az elbeszélés módozatai [Modalities of Narration], eds. Ildikó Józan, Ernő Kulcsár Szabó and Mihály Szegedy-Maszák, 501-520. Budapest: Osiris.

Papp, Klaudia. 2007. "Múfaji apóriák és melankólia Anita Brookner Tóparti szálloda címú regényében." ["Generic Aporia and Melancholy in Anita Brookner's Hotel du Lac."] In A nó mint szubjektum - a nói szubjektum [The Female as Subject - The Feminine Subject], ed. Nóra Séllei, 205-215. Debrecen: Debrecen University Press. 
Sántha, József. 2015. “Az érzékiség oskolája.” [“The School of Sensuality.”] Review. http://www.revizoronline.com/hu/cikk/5469/ugron-zsolna-a-nadorasszonyai/ (Last accessed 02 April 2016)

Séllei, Nóra, ed. 2007. A nó mint szubjektum - a nói szubjektum [The Female as Subject - The Feminine Subject]. Debrecen: Debrecen University Press.

Sinka, Annamária. 2011. "A vessző eddig hiányzott: lány, regény vs. lányregény." ["The Coma Was So Far Missing: Girls, Novel vs. Girls' Novel.”] Híd no. 3 (March): 89-98. http://www.hid.rs/hid/2011/hid-2011-03.pdf (Last accessed 30 March 2016)

Storey, John. 2003. "Postmodernism and Popular Culture." In The Routledge Companion to Postmodernism, ed. Stuart Sim, 147-157. London and New York: Routledge.

Szalai, Anikó. 2011. "Pesti lány esete az erdélyi kastélyokkal.” ["The Case of the Girl from Budapest with Transylvanian Castles.”] http://kulter.hu/2011/05/ pesti-lany-esete-az-erdelyi-kastelyokkal/ (Last accessed 31 March 2016)

Szirák, Péter. 2001. "A magyar irodalmi posztmodernség értelmezéséhez." ["To the Interpretation of the Hungarian Literary Postmodern."] In A magyar irodalmi posztmodernség [The Hungarian Literary Postmodern], ed. Péter Szirák, 9-53. Debrecen: Debrecen University Press.

Tapodi, Zsuzsa. 2008. A soha el nem veszố könyv nyomában. [On the Tracks of the Book that Never Gets Lost.] Miercurea-Ciuc: Pallas-Akadémia.

Tomoko, Aoyama. 2000. "Literary Daughters' Recipes. Food and Female Subjectivity in the Writings of Mori Mari and Koda Aya." Japan Studies: 91-116. http://www.dijtokyo.org/doc/dij-jb_12-aoyama.pdf (Last accessed 31 March 2016)

Ugron, Zsolna. 2010. Úrilányok Erdélyben. [By the Black River - A Transylvanian (Love) Story.] Budapest: Ulpius.

Ugron, Zsolna and Zsolt Meskó. 2011. Szerelemféltók. [The A - B Dialogue.] Budapest: Ulpius.

Ugron, Zsolna. 2013a. Erdélyi menyegzó. [Splendour.] Budapest: Libri.

Ugron, Zsolna. 2013b. Hét évszak. Receptek és történetek. [Seven Seasons. Recipes and Stories.] Budapest: Boook.

Ugron, Zsolna. 2014. A nádor asszonyai. [The Palatine's Women.] Budapest: Libri.

Ugron, Zsolna. 2016. Hollóasszony. [Ravenwoman.] Budapest: Libri.

Varga, Melinda. 2011. Interview with Zsolna Ugron. "Belénk égették a hagyományokat." [“Traditions Are Engraved into Us."] http://www. irodalmijelen.hu/05242013-1513/belenk-egettek-hagyomanyokat-interjuugron-zsolnaval (Last accessed 30 March 2016) 
Virginás, Andrea. 2014. "Kortárs kelet-európai nőképek: irodalmi és filmes példák.” [“Contemporary Eastern-European Women's Images: Literary and Cinematographic Examples.”] TNTeF vol. 4. no. 2.: 37-54.

Woolf, Virginia. 1996. Mrs. Dalloway. London: Penguin.

Zohar, Itamar Even. 1990. "Polysystem Studies.” In Poetics Today vol. 11. no. 1. http://www.tau.ac.il/ itamarez/works/books/ez-pss1990.pdf (Last accessed 30 March 2016) 